\title{
Research on the Evaluation Index System of the Effectiveness of Food Quality Safety Market Admittance System
}

\author{
Xiangrong Zhang \\ Shenzhen Graduate School, Harbin Institute of Technology \\ Approval and review center, Market Supervision Administration of Shenzhen Municipality \\ Guangdong 518040, China \\ E-mail: zhangxiangrong5@163.com \\ Susheng Wang \\ Shenzhen Graduate School, Harbin Institute of Technology \\ Guangdong 518055, China
}

Received: December 28, 2010 Accepted: March 17, 2011 doi:10.5539/jas.v3n3p240

\begin{abstract}
The occurrence of food safety incidents such as "Sanlu Milk Powder" make the public have doubts about the effectiveness of food quality safety market admittance system. Therefore, studying and evaluating the effectiveness of food quality safety market admittance system has become a problem to solve urgently. The article combines the theory of management science with the practice of food quality safety market admittance system, and explores and builds a set of evaluation index system of the effectiveness of food quality safety market admittance system, laying the foundation for the evaluation of the system.
\end{abstract}

Keywords: Food quality safety market admittance system, Effectiveness, Evaluation index system

\section{Introduction}

Since the General Administration of Quality Supervision started food quality safety market admittance system in July 2002, the system has made elaborate deployments from its strategic planning to specific implementation, which plays an important role in the aspects including regulating market order, prompting food industry development, ensuring food quality safety and guaranteeing the heath and lives security of customers. However, recently many food safety incidents especially "Sanlu Milk Powder" event make the public have doubts about the effectiveness of food quality safety market admittance system which undertakes the responsibility of safety supervision. Therefore, research on the evaluation of the effectiveness of food quality safety market admittance system has become an issue to solve urgently. From the perspective of management science, research on the evaluation of the effectiveness of food quality safety market admittance system includes two aspects: 1) how to build the evaluation index system of the effectiveness of the system; 2) how to apply the evaluation index system to draw the conclusion whether the system is effective. Therefore, building the evaluation index system of the effectiveness of food quality safety market admittance system is the premise of carrying out its effectiveness evaluation.

\section{The establishment of the framework of the evaluation index system of the effectiveness of food quality safety market admittance system}

There are many ways to build the framework of the evaluation index system of the effectiveness of a system. Currently in the practical field of foreign government, the mature evaluation system framework is more based on the idea of balance score card. In 1980s, western countries raise "new public management movement" aiming at pursuing economy, efficiency and benefit successively in the field of public management, which advocated to introduce the theory, method and technology of business administration to public management in order to improve public management levels and public service quality. In the movement, the balance score card which was used in the effectiveness of enterprise management before was introduced into the government management of developed countries firstly (Robert S. Kaplan \& David P. Norton, 2004). A great number of successful cases have shown the remarkable performance of balance score card. Since Clinton signed Government Performance and Results Act in 1993 in America, balance score card has been introduced into the effectiveness assessment of 
government management and obtained obvious effects. Such agencies as the city of Charlotte, the U. S. Department of Defense, the U. S. Department of Transportation, the U. S. federation aviation agency, the U. S. defense logistics agency, the U. S. Air Force and Navy have applied balance score card widely and successfully. Not only the U. S., currently but the U. K, Australia, Sweden, Canada have started to take balance score card as the tool of managing the effectiveness of public policy implementation and obtained good effects.

The rise of the management idea of balance score card is used to solve the problem of enterprise management effectiveness mainly. It starts from the strategy of corporate development and transforms corporate strategic target to four diverse and interrelated targets below: financial situations, customer service, internal process, learning and growth. It thinks an enterprise should evaluate the effectiveness of enterprise management through collecting information about the four aspects and further improve corporate management level. Using the idea above to see the effectiveness assessment of the implementation of government system currently, such four aspects as system cost, system performance, the internal process of system management and system development can be used to evaluate the effectiveness of system development, and the difference and relation between each other is shown in table 1.

From the comparison above we can see, to use the idea of balance score card to carry out system effectiveness evaluation conforms to China's administrative concept of scientific progress view. It realizes the arrangement of three aspects when considering the effectiveness of the system as follows: 1) it integrates and considers the performance and process factors of the system implementation, which thinks system effectiveness cannot be judged just according to short-term system performance index, but to consider the process of system implementation. Normative process of system implementation is the base to ensure long-term performance of the system. 2) it integrates and considers the factors of the system such as its real performance and future development. It thinks the development aftereffects of the system should also be introduced into the assessment of system effectiveness and thus avoid some short-term behavior of system implementation, conductive to the sustainable development of system implementation; 3) it integrates and considers the balance of the system implementation between its performance and financial indexes. Although it's not necessary for the government to consider the direct profitability of the system, the government pays taxpayers' money for public products and the public hope to realize the maximum of welfares. Therefore, the effectiveness of each system has to consider what the cost is in order to realize its performance.

Food quality safety market admittance system is an important administrative licensing system implemented by the government for the public food safety, and it belongs to the category of government system. Therefore, according to the analysis above, its effectiveness evaluation system should include the following four parts: system cost, system performance, the internal process of the system and system development.

\section{The confirmation of sub-indexes about the effectiveness evaluation index system of food quality safety market admittance system}

\subsection{The principle of index confirmation}

After confirming the framework of the system, each index below the framework needs to be divided into sub-index. Because the process of effectiveness evaluation of food quality safety market admittance system is a process that collects and processes information according to the sub-indexes of the system. In order to increase the scientificity of the evaluation, the design of sub-indexes has to follow the following principles:

1) Integrity principle: firstly, require each index can reflects the requirements of the system effectiveness globally; secondly, require there's organic link and interconnection between each specific index in order to reflect the effectiveness of the system comprehensively and systematically.

2) Measurability principle: measurability requires the indexes are quantitative as possible as they can, and the stipulated contents can draw definite conclusions using current management tools. For the indexes not quantitative, qualitative description should also has direct measurability, which means to identify corresponding grades such as excellence and good easily.

3) Feasibility principle: firstly, the acquirement of indexes should have smooth information source. If the channel is not smooth, sufficient related information cannot be obtained. No matter how good the evaluation indexes are, it's always virtual. Secondly, there's scientific method to obtain information, by means of test, questionnaire and interview to obtain evaluation information.

\subsection{The confirmation of specific index}

According to the principles above, under the framework of balance score card, the specific index of each part is confirmed as follows: 
(1) The index of system cost. Finance and cost factors are the primary indexes concerned by the practice of effectiveness evaluation, which means all the expense cost in order to realize the effectiveness of the system. According to current operation mode of food quality safety system, system cost mainly includes two parts of fees: one is the fee produced in the process of system implementation, the other is the fee in order to support the smooth progress of the system, specific see a table 2 .

(2) The index of system performance. In the conditions of market economy, the government provides quality public products and services according to the requirements of social development and needs of the public. Therefore, measuring the performance of each public system firstly needs to see the satisfaction of its service objects. Specific to food quality safety market admittance system, it should include the satisfaction of food enterprises and customers. In addition, according to the explanation about quality safety supervision and administration measures in food production and processing enterprises, the specific target of the system is to improve the level of food quality safety through normalizing the production conditions of food production and processing enterprises. Therefore, the enhancement of food quality and food production and processing enterprise quality management levels should also become an important index of the system performance, in which the former can be measured by pass rate of food, the latter can be measured by the proportion of $\mathrm{C}$ enterprises in total enterprises with certificate, specific to see table 3.

(3) Internal process index of system management. Perfect and ordered internal operation processes of system management is the key to ensure good level of system effectiveness. The formulation of the indexes is based on the processes of system implementation. Currently the implementation of food quality safety market admittance system includes two primary links: issuance of certificate and supervision after issuance. The links of issuance of certificate inside the government include: application and acceptance, site inspection, certification checking, issuance of certificate and announcement. According to the characteristics of each process, it's measured by material error rate, site inspection satisfaction, certificate checking satisfaction, and the degree of timeliness of issuance of certificate and announcement respectively. Supervision after issuance mainly includes such methods as patrol, return visit, random supervision and checking, and law enforcement inspection, and it's measured by the numbers of patrolling and return visit, random supervision and checking, and law enforcement inspection respectively. In addition, the working style and clean government situations in the process of government system implementation are important aspects to consider when the system implements, measured by window service satisfaction and the number of corruption cases respectively, specific to see table 4 .

(4) The index of system development. System development is a factor which starts from potential factors such as system reform and development to predict the long-term level of the system. The executer of the system is people, and the learning and innovation capacity of human resource who implements the system is the determinant factor of system development. The people who implements food quality safety market admittance system are inspectors and relevant managers, whose learning and innovation capacity is measured by the proportion with bachelor degree or above, training time and scientific and technological innovation results. In addition, the reasonability of the plan of the system is also an important aspect of system development and it's measured by satisfaction of the plan of the system, specific to see table 5 .

\section{The confirmation of the weights of the effectiveness evaluation index system of food quality safety market admittance system}

\subsection{The way to confirm the weights of system indexes}

The effectiveness evaluation index system of food quality safety market admittance system is a multi-hierarchy and multi-indexes complex system. In the complex system, the relative importance of each hierarchy and index is different so it's difficult to confirm. Common methods such as valuation based on experiences and experts are not effective even impossible. The analytic hierarchy process (AHP) is a good way to confirm the system scientifically, whose main thought is: weights are the importance of each index relative to the total index. Total index is consisted of different sub-indexes and then the importance of each index relative to total index can be obtained from the comparisons of this index to other indexes with the same hierarchy(Xu, Shubai, 1998). Specific procedures are as follows:

First step: confirm the importance degrees form of comparisons. Generally speaking, because the hierarchy that people can identify is five below: equally important, slightly important, obviously important, very important, extremely important. Different degrees of importance are shown by the number 1, 3, 5, 7, 9 .

Second step: confirm the judgment matrix of comparisons. The values of indexes in the judgment matrix can be obtained comprehensively according to research data, statistical materials, government work report and expert opinion. 
Third step: according to the judgment matrix calculate the weight of each index relative to the upper index. The procedure is mathematical calculation according to the judgment matrix established in the former step. Due to space limitations, the article doesn't discuss it in details.

Fourth step: confirm the form of weights according to the importance of each index relative to the upper index.

\subsection{Confirmation results of the system indexes weights}

According to the method above, the authors carried out preliminary survey based on questionnaire about food experts in the city of Shenzhen. The judgment matrix of each index was confirmed and the result of the system indexes weights was obtained after mathematical calculation as shown in the table 6 .

\section{Conclusions and prospect}

Combined the management idea of balance score card with the practice of food quality safety market admittance system, the article builds a set of indexes to evaluate the effectiveness of the system comprehensively and systematically and confirms the weights of specific indexes using the analytic hierarchy process, laying the foundation for the effectiveness evaluation of the system. Subjected to the knowledge and experience of the authors, the following work can be studied in depth: 1) aiming at the structure of the judgment matrix between specific indexes and indexes of different layers, further research can be done in a much greater scale and thus improve the scientificity of specific indexes and their weights. 2) after confirming the index system, research on how to apply the system to the evaluation combined with the real situations should be done and thus perfect the evaluation research work of the system.

\section{References}

Robert S.Kaplan \& David P.Norton. (2004). Strategy-Focused Organization. Translated by Zhou, Dayong. Beijing: People's Post and Telecommunication Publishing House. Pp. 138.

The General Administration of Quality Supervision, Inspection and Quarantine. (2003). The explanation about quality safety supervision and administration measures in food production and processing enterprises. Beijing: Standards Press of China. Pp. 6-7.

$\mathrm{Xu}$, Shubai. (1998). The principle of hierarchy analysis approach: practical decision method. Tianjin: Tianjin University press. Pp. 25.

Table 1. Difference and relation of balance score card in implementing effectiveness assessment of enterprise management and government system

\begin{tabular}{|c|c|c|}
\hline No. & $\begin{array}{l}\text { The application of balance score card in the } \\
\text { effectiveness of the implementation of } \\
\text { enterprise management and government } \\
\text { system }\end{array}$ & difference and relation \\
\hline \multirow[b]{2}{*}{1} & Financial situation & $\begin{array}{l}\text { Enterprises must have profitability. The effectiveness of enterprise } \\
\text { management needs to see its management cost and its profitability } \\
\text { in this management mode. }\end{array}$ \\
\hline & System cost & $\begin{array}{l}\text { The public system of government has no profitability directly. The } \\
\text { financial assessment of the effectiveness of the system needs to see } \\
\text { the cost in the situation that the system realizes certain performance } \\
\text { mainly. }\end{array}$ \\
\hline \multirow[t]{2}{*}{2} & Customer service & $\begin{array}{l}\text { In the process of transformation of market from seller to buyer, the } \\
\text { concept whether customers' needs are meet bitterly is one of most } \\
\text { basic and important corporate management effectiveness. }\end{array}$ \\
\hline & System performance & $\begin{array}{l}\text { To provide quality public products for the public and enterprises is } \\
\text { the main reflection of the effectiveness of public policy. }\end{array}$ \\
\hline \multirow{2}{*}{3} & Corporate internal process & $\begin{array}{l}\text { The realization of the target of corporate finance and customer } \\
\text { services need good internal operation and processes to support. }\end{array}$ \\
\hline & Internal process of system implementation & $\begin{array}{l}\text { The realization of public policy target needs good governmental } \\
\text { internal operation and process to support. }\end{array}$ \\
\hline \multirow[t]{2}{*}{4} & Learning and growth & $\begin{array}{l}\text { In the times of knowledge economy, only the enterprise with good } \\
\text { learning and growth capacity keeps the effectiveness of long-term } \\
\text { management. }\end{array}$ \\
\hline & System development & $\begin{array}{l}\text { The effectiveness of system implementation should be considered } \\
\text { combined short-term and long-term development. }\end{array}$ \\
\hline
\end{tabular}


Table 2. The score card of system cost

\begin{tabular}{|c|c|c|}
\hline Sub-index & Specific index & $\begin{array}{l}\text { Information source and acquirement } \\
\text { method }\end{array}$ \\
\hline \multirow{5}{*}{$\begin{array}{l}\text { The cost of system } \\
\text { implementation }\end{array}$} & Site verification fee (Yuan) & $\begin{array}{l}\text { Obtain from statistical reports submitted } \\
\text { by food quality supervision offices of } \\
\text { Quality and Technical Supervision } \\
\text { bureau }\end{array}$ \\
\hline & Certificate and inspection fee(Yuan) & $\begin{array}{l}\text { Obtain specific situations about } \\
\text { certificate from statistical reports } \\
\text { submitted by food quality supervision } \\
\text { offices of Quality and Technical } \\
\text { Supervision bureau, and then calculate } \\
\text { according to the provisions of national } \\
\text { standards. }\end{array}$ \\
\hline & $\begin{array}{l}\text { Food } \quad \text { supervision } \\
\text { expenditure(Yuan) }\end{array}$ & $\begin{array}{l}\text { Obtain from financial statements of } \\
\text { Quality and Technical Supervision } \\
\text { bureau }\end{array}$ \\
\hline & Scientific research fee(Yuan) & $\begin{array}{l}\text { Obtain from the report submitted by } \\
\text { scientific research management office of } \\
\text { Quality and Technical Supervision } \\
\text { bureau }\end{array}$ \\
\hline & $\begin{array}{l}\text { Office and staff cost of the department of } \\
\text { system implementation(Yuan) }\end{array}$ & $\begin{array}{l}\text { Obtain from financial statements of } \\
\text { Quality and Technical Supervision } \\
\text { bureau }\end{array}$ \\
\hline
\end{tabular}

Table 3. the score card of system performance

\begin{tabular}{|l|l|l|}
\hline Sub-index & Specific index & $\begin{array}{l}\text { Information source and acquirement } \\
\text { method }\end{array}$ \\
\hline \multirow{5}{*}{ System performance } & Food enterprise satisfaction (\%) & $\begin{array}{l}\text { Obtain from investigation about food } \\
\text { enterprise satisfaction }\end{array}$ \\
\cline { 2 - 3 } & Customer satisfaction(\%) & $\begin{array}{l}\text { Obtain from investigation about customer } \\
\text { satisfaction }\end{array}$ \\
\cline { 2 - 3 } & Pass rate of food(\%) & $\begin{array}{l}\text { Obtain from inspection organization of } \\
\text { Quality and Technical Supervision bureau }\end{array}$ \\
\cline { 2 - 3 } & $\begin{array}{l}\text { proportion of C enterprises in total } \\
\text { enterprises with certificate(\%) }\end{array}$ & $\begin{array}{l}\text { Obtain from food supervision office of } \\
\text { Quality and Technical Supervision bureau }\end{array}$ \\
\hline
\end{tabular}

Table 4. the score card of internal process of system management

\begin{tabular}{|c|c|c|}
\hline Sub-index & Specific index & Information source and acquirement method \\
\hline \multirow{9}{*}{$\begin{array}{l}\text { internal process of } \\
\text { system management }\end{array}$} & Material error rate $(\%)$ & $\begin{array}{l}\text { Obtain from food supervision office of } \\
\text { Quality and Technical Supervision bureau }\end{array}$ \\
\hline & Site inspection satisfaction(\%) & $\begin{array}{l}\text { Obtain from the investigation of satisfaction } \\
\text { in food enterprises }\end{array}$ \\
\hline & certificate checking satisfaction( $\%)$ & $\begin{array}{l}\text { Obtain from the investigation of satisfaction } \\
\text { in food enterprises }\end{array}$ \\
\hline & $\begin{array}{l}\text { the degree of timeliness of issuance of } \\
\text { certificate and announcement }(\%)\end{array}$ & $\begin{array}{l}\text { Obtain from the investigation of satisfaction } \\
\text { in food enterprises }\end{array}$ \\
\hline & $\begin{array}{l}\text { The number of patrolling and return } \\
\text { visit }\end{array}$ & $\begin{array}{l}\text { Obtain from patrolling organization of Quality } \\
\text { and Technical Supervision bureau }\end{array}$ \\
\hline & $\begin{array}{l}\text { The number of random supervision and } \\
\text { checking }\end{array}$ & $\begin{array}{l}\text { Obtain from inspection organization of } \\
\text { Quality and Technical Supervision bureau }\end{array}$ \\
\hline & $\begin{array}{l}\text { The number of law enforcement } \\
\text { inspection }\end{array}$ & $\begin{array}{l}\text { Obtain from auditing organization of Quality } \\
\text { and Technical Supervision bureau }\end{array}$ \\
\hline & window service satisfaction( $\%$ ) & $\begin{array}{l}\text { Obtain from the investigation of satisfaction } \\
\text { in food enterprises }\end{array}$ \\
\hline & the number of corruption cases & $\begin{array}{l}\text { Obtain from censorial organization of Quality } \\
\text { and Technical Supervision bureau }\end{array}$ \\
\hline
\end{tabular}


Table 5. the scoring card of system development

\begin{tabular}{|c|c|c|}
\hline Sub-index & Specific index & $\begin{array}{l}\text { Information source and acquirement } \\
\text { method }\end{array}$ \\
\hline \multirow{5}{*}{ system development } & $\begin{array}{l}\text { the proportion of inspectors with bachelor } \\
\text { degree or above }\end{array}$ & $\begin{array}{l}\text { Obtain from the censors of Quality and } \\
\text { Technical Supervision bureau }\end{array}$ \\
\hline & $\begin{array}{l}\text { the proportion of relevant managers with } \\
\text { bachelor degree }(\%)\end{array}$ & $\begin{array}{l}\text { Obtain from the censors of Quality and } \\
\text { Technical Supervision bureau }\end{array}$ \\
\hline & Training time(day) & $\begin{array}{l}\text { Obtain from food supervision office of } \\
\text { Quality and Technical Supervision bureau }\end{array}$ \\
\hline & $\begin{array}{l}\text { scientific and technological innovation } \\
\text { results }\end{array}$ & $\begin{array}{l}\text { Obtain from the achievement report } \\
\text { submitted by scientific research office of } \\
\text { Quality and Technical Supervision bureau }\end{array}$ \\
\hline & $\begin{array}{l}\text { satisfaction of long-term plan of the } \\
\text { system(\%) }\end{array}$ & $\begin{array}{l}\text { Obtain from the investigation of } \\
\text { satisfaction aiming to the managers related } \\
\text { to the system in Quality and Technical } \\
\text { Supervision bureau }\end{array}$ \\
\hline
\end{tabular}

Table 6. the form of the confirmation results of the system indexes weights

\begin{tabular}{|c|c|c|}
\hline Total index & Sub-index & Specific index \\
\hline \multirow{23}{*}{$\begin{array}{l}\text { Total index of the } \\
\text { effectiveness } \\
\text { evaluation of food } \\
\text { quality safety } \\
\text { market admittance } \\
\text { system(1.000000) }\end{array}$} & \multirow{5}{*}{$\begin{array}{l}\text { The cost of system } \\
\text { implementation } \\
(0.095507)\end{array}$} & Site inspection fee(Yuan)(0.010103) \\
\hline & & certificate checking fee(Yuan) (0.010103) \\
\hline & & Food supervision expenditure (Yuan) (0.048784) \\
\hline & & Scientific research fee(Yuan) $(0.004886)$ \\
\hline & & $\begin{array}{l}\text { The cost of office and staff in the department of system } \\
\text { implementation (Yuan) }(0.021632)\end{array}$ \\
\hline & \multirow{4}{*}{$\begin{array}{l}\text { System performance } \\
(0.654467)\end{array}$} & Food enterprise satisfaction(\%) $(0.077087)$ \\
\hline & & Customer satisfaction (\%) (0.172372) \\
\hline & & Pass rate of food $(\%)(0.368997)$ \\
\hline & & $\begin{array}{l}\text { proportion of } \mathrm{C} \text { enterprises in total enterprises with } \\
\text { certificate }(\%)(0.036010)\end{array}$ \\
\hline & \multirow{9}{*}{$\begin{array}{l}\text { Internal process of system } \\
\text { management } \\
(0.204451)\end{array}$} & Material error rate(\%) $(0.005974)$ \\
\hline & & Site inspection satisfaction(\%) (0.054581) \\
\hline & & Certificate checking satisfaction $(0.017922)$ \\
\hline & & $\begin{array}{l}\text { the degree of timeliness of issuance of certificate and } \\
\text { announcement }(\%)(0.005974)\end{array}$ \\
\hline & & The number of patrolling and return visit $(0.017922)$ \\
\hline & & $\begin{array}{l}\text { The number of random supervision and checking } \\
(0.031686)\end{array}$ \\
\hline & & The number of law enforcement inspection (0.009836) \\
\hline & & window service satisfaction(\%) (0.005974) \\
\hline & & the number of corruption cases $(0.054581)$ \\
\hline & \multirow{5}{*}{$\begin{array}{l}\text { System development } \\
(0.045575)\end{array}$} & $\begin{array}{l}\text { the proportion of inspectors with bachelor degree or } \\
\text { above }(\%)(0.013579)\end{array}$ \\
\hline & & $\begin{array}{l}\text { the proportion of relevant managers with bachelor } \\
\text { degree }(\%)(0.007192)\end{array}$ \\
\hline & & Training time(day) $(0.004034)$ \\
\hline & & $\begin{array}{l}\text { scientific and technological innovation results } \\
(0.007192)\end{array}$ \\
\hline & & $\begin{array}{lccc}\text { satisfaction of long-term } & \text { plan } & \text { of } \\
\text { system(\%)(0.013579) }\end{array}$ \\
\hline
\end{tabular}

